\title{
PHYSIOLOGICAL FACTORS AFFECTING TOTAL CELL NUMBER AND LIPID CONTENT OF THE YEAST, LIPOMYCES STARKEYI
}

\author{
TAKAFUMI NAGANUMA, YASUYUKI UZUKA \\ AND KENTARO TANAKA \\ Department of Fermentation Technology, Faculty of \\ Engineering, Yamanashi University, Takeda-4 \\ Kofu 400, Japan
}

(Received January 17, 1985)

The effects of the concentration of the medium components and other cultural conditions on the total cell number and on the lipid content (mg of total lipid $/ 10^{8}$ cells) of the fat yeast Lipomyces starkeyi were examined. The no addition and deficiency of $\mathrm{NH}_{4}{ }^{+}, \mathrm{K}^{+}, \mathrm{Mg}^{2+}, \mathrm{PO}_{4}{ }^{3-}$, $\mathrm{SO}_{4}{ }^{2-}, \mathrm{Zn}^{2+}, \mathrm{Fe}^{3+}$, or $\mathrm{Mn}^{2+}$ decreased the total cell number. $\mathrm{Mn}^{2+}$ sufficiency increased the total cell number by a factor of 1.5 to 1.7 , as compared with that of the standard concentration. The lipid content of the yeast was affected by $\operatorname{six}\left(\mathrm{NH}_{4}{ }^{+}, \mathrm{K}^{+}, \mathrm{Ca}^{2+}, \mathrm{Zn}^{2+}, \mathrm{Fe}^{3+}\right.$, and $\left.\mathrm{Mn}^{2+}\right)$ ion concentrations. The no addition and deficiency of $\mathrm{Zn}^{2+}$ increased the lipid content by a factor ranging from 2.4 to 2.8 in comparison with that of the standard concentration. The concentration of $\mathrm{Zn}^{2+}$ also altered the lipid yield ( $\mathrm{g}$ of lipid/100 $\mathrm{g}$ of glucose consumed) considerably. The concentration of $\mathrm{Na}^{+}, \mathrm{Cl}^{-}, \mathrm{Cu}^{2+}, \mathrm{BO}_{3}{ }^{3-}, \mathrm{I}^{-}, \mathrm{MoO}_{4}{ }^{2-}$, and biotin had almost no effect on the total cell number, lipid content, and lipid yield of $L$. starkeyi. The cultural temperature and the initial $\mathrm{pH}$ value of the medium affected the total cell number and lipid content; the optimum temperature ranged from 25.5 to $29.5^{\circ} \mathrm{C}$, and the optimum $\mathrm{pH}$ value was 4.9. A low concentration of dissolved oxygen decreased both the total cell number and lipid content. D-Glucose, D-mannose, D-galactose, Dlevulose, sucrose, D-xylose, and L-arabinose proved to be usable carbon sources for the growth and the lipid accumulation of L. starkeyi.

Some yeasts accumulate a large amount of lipid in the cells. Although studies on lipid accumulation of microorganisms have been conducted since 1878, few reports on the physiological factors of lipid accumulation of yeasts have been published (1-4). The previous research conducted at our laboratory suggested that only a few trace elements affect the growth and the intracellular lipid (mainly 
triglyceride) content of the fat yeast, Lipomyces starkeyi $(5,6)$. The effects of these trace elements have been examined independently for each individual experiment. Therefore, the data from these experiments is insufficient for comparison with each other, and does not provide insight into understanding the total relationship between physiological factors and lipid accumulation.

In this study, the effects of the concentration of the medium components, cultural conditions, and carbon sources on the total cell number and on the lipid content of $L$. starkeyi were systematically examined.

\section{MATERIALS AND METHODS}

Organism and cultural conditions. The organism used in this work was Lipomyces starkeyi IAM 4753. A stock culture and seed culture were prepared as described previously (7). The yeast was grown under aerobic conditions at $29.5^{\circ} \mathrm{C}$ with a reciprocal shaker (amplitude $7 \mathrm{~cm}, 120 \mathrm{rpm}$ ). Samples were taken at the stationary phase of growth (usually around $100 \mathrm{hr}$ ).

Composition of standard medium. The standard medium consisted of $\mathrm{D}$ glucose, $30.0 \mathrm{~g} ;\left(\mathrm{NH}_{4}\right)_{2} \mathrm{SO}_{4}, 5.3 \mathrm{~g} ; \mathrm{KH}_{2} \mathrm{PO}_{4}, 1.0 \mathrm{~g} ; \mathrm{MgSO}_{4} \cdot 7 \mathrm{H}_{2} \mathrm{O}, 0.5 \mathrm{~g} ; \mathrm{NaCl}$, $0.1 \mathrm{~g} ; \mathrm{CaCl}_{2} \cdot 2 \mathrm{H}_{2} \mathrm{O}, 0.1 \mathrm{~g} ; \mathrm{FeCl}_{3} \cdot 6 \mathrm{H}_{2} \mathrm{O}, 2.4 \mathrm{mg} ; \mathrm{ZnSO}_{4} \cdot 7 \mathrm{H}_{2} \mathrm{O}, 330.0 \mu \mathrm{g} ; \mathrm{MnCl}_{2} \cdot$ $4 \mathrm{H}_{2} \mathrm{O}, 79.0 \mu \mathrm{g} ; \mathrm{CuCl}_{2} \cdot 2 \mathrm{H}_{2} \mathrm{O}, 18.8 \mu \mathrm{g} ; \mathrm{Na}_{2} \mathrm{MoO}_{4} \cdot 2 \mathrm{H}_{2} \mathrm{O}, 3.2 \mu \mathrm{g} ; \mathrm{KI}, 13.0 \mu \mathrm{g}$; $\mathrm{H}_{3} \mathrm{BO}_{3}, 42.9 \mu \mathrm{g}$; D-biotin, $0.2 \mu \mathrm{g}$ in $1,000 \mathrm{ml}$ of water which was deionized and subsequently distilled twice with an all glass unit. The $\mathrm{pH}$ value of the medium was adjusted to 5.3 with $0.2 \mathrm{~N} \mathrm{KOH}$ and $0.2 \mathrm{M} \mathrm{H}_{3} \mathrm{PO}_{4}$ before sterilization. Chemicals were of the highest grade (Wako Pure Chemical Industries, Ltd., Osaka, Japan). One hundred $\mathrm{ml}$ of the medium was transferred in a $500-\mathrm{ml}$ shaking flask. The flask was plugged with cotton and autoclaved at $115^{\circ} \mathrm{C}$ for $10 \mathrm{~min}$. After autoclaving the $\mathrm{pH}$ value of the medium was 4.8-5.0.

Measurements of total cell number, lipid content and lipid yield. The total number of cells was counted with a hemacytometer (5). The total lipid (mainly triglyceride) was extracted by disrupting the cells with glass beads, and by mixing the cells well with chloroform-methanol (5). Total lipid was measured by gravimetric determination, and the lipid content was calculated as weight (mg) of total cellular lipid per $10^{8}$ cells. The lipid yield is defined as grams of total lipid produced per $100 \mathrm{~g}$ of the carbon source consumed (8). Each reported value was the average of three measurements.

Measurement of residual carbon source in the medium. Glucose in the culture medium was assayed by a diagnostic assay kit (Glucose C-Test Wako, Wako Pure Chemical Industries, Ltd.). Other carbohydrates were determined by the phenol- $\mathrm{H}_{2} \mathrm{SO}_{4}$ method (9). Citric acid was assayed by high-performance liquidchromatography (10).

Control and determination of dissolved oxygen concentration in the medium. For the restriction of dissolved oxygen concentration, the cotton plug on 500-ml 
shaking flask containing $100 \mathrm{ml}$ of the medium was covered with polyethylenefilm (thickness $0.06 \mathrm{~mm}$ ). To achieve high concentration of dissolved oxygen, $50 \mathrm{ml}$ of the medium was transferred into a $500-\mathrm{ml}$ shaking flask. The standard condition was $100 \mathrm{ml}$ of the medium in a $500-\mathrm{ml}$ shaking flask. Dissolved oxygen concentration in the culture medium was monitored continuously with an oxygenelectrode (DKK Type 7606, Denki Kagaku Keiki Co., Ltd., Tokyo, Japan). This was connected to a trip amplifier. The output signal from the trip amplifier was recorded.

\section{RESULTS}

Many factors were to be examined in this study, therefore the experiments were divided into 20 separate culture groups. Each culture group contained a standard experimental case. Some variance was seen among the standard experimental cases, thus the experimental results were compared and discussed within each culture group. Experimental results are shown in the following order: effects of major cations (Tables 1 and 2); effects of major anions (Table 3); effects of minor cations (Table 4); effects of minor anions (Table 5); effects of cultural conditions (Table 6); effects of glucose concentration and carbon sources (Table 7).

Factors affecting total cell number

L. starkeyi showed almost no growth in the medium without $\mathrm{NH}_{4}{ }^{+}, \mathrm{K}^{+}$,

Table 1. Effects of major cations ( I ).

\begin{tabular}{clccc}
\hline Ion [compound] & \multicolumn{1}{c}{$\begin{array}{c}\text { Ion } \\
\text { concentration } \\
(\mathrm{g} / \mathrm{l})\end{array}$} & $\begin{array}{c}\text { Total cell } \\
\text { number } \\
\left(\times 10^{8} / \mathrm{ml}\right)\end{array}$ & $\begin{array}{c}\text { Lipid content } \\
\left(\mathrm{mg} / 10^{8}\right. \\
\text { cells })\end{array}$ & $\begin{array}{c}\text { Lipid yield } \\
\text { (g of lipid/ } \\
100 \mathrm{~g} \text { of } \\
\text { glucose } \\
\text { consumed })\end{array}$ \\
\hline $\mathrm{NH}_{4}{ }^{+}\left[\left(\mathrm{NH}_{4}\right)_{2} \mathrm{SO}_{4}\right]$ & 0 (no addition) & 0.04 & & \\
& 0.13 & 1.5 & 1.9 & 13 \\
& 0.45 & 2.2 & 1.3 & 10 \\
& 1.34 (standard) & 2.4 & 1.2 & 10 \\
$\mathrm{~K}^{+}[\mathrm{KCl}]^{a}$ & 4.07 & 2.3 & 1.3 & 10 \\
& 0 (no addition) & 0.07 & & 9 \\
& 0.03 & 0.3 & 0.6 & 10 \\
& 0.11 & 1.3 & 2.1 & 9 \\
$\mathrm{Mg}^{2+}$ & 0.32 (standard) & 1.6 & 1.6 & 9 \\
{$\left[\mathrm{MgSO}_{4} \cdot 7 \mathrm{H}_{2} \mathrm{O}\right]$} & 1.58 & 2.1 & 1.3 & 10 \\
& 0 (no addition) & 0.05 & & 9 \\
& 0.01 & 1.9 & 1.6 & 9 \\
\hline
\end{tabular}

$a \quad \mathrm{KH}_{2} \mathrm{PO}_{4}$ and $\mathrm{KI}$ were excluded from medium. $\mathrm{NaH}_{2} \mathrm{PO}_{4} \cdot 2 \mathrm{H}_{2} \mathrm{O}$ and $\mathrm{NaI}$ were added as $\mathrm{PO}_{4}{ }^{3-}$ and $\mathrm{I}^{-}$sources. $\mathrm{pH}$ of medium was adjusted with $0.2 \mathrm{~N} \mathrm{NaOH}$ instead of $0.2 \mathrm{~N} \mathrm{KOH}$. 
Table 2. Effects of major cations ( II ).

\begin{tabular}{clccc}
\hline Ion [compound] & \multicolumn{1}{c}{$\begin{array}{c}\text { Ion } \\
\text { concentration } \\
(\mathrm{g} / l)\end{array}$} & $\begin{array}{c}\text { Total cell } \\
\text { number } \\
\left(\times 10^{8} / \mathrm{ml}\right)\end{array}$ & $\begin{array}{c}\text { Lipid content } \\
\left(\mathrm{mg} / 10^{8}\right. \\
\text { cells })\end{array}$ & $\begin{array}{c}\text { Lipid yield } \\
(\mathrm{g} \text { of lipid/ } \\
100 \mathrm{~g} \text { of } \\
\text { glucose } \\
\text { consumed) }\end{array}$ \\
\hline $\mathrm{Ca}^{2+}$ & 0 (no addition) & 1.8 & 1.3 & 8 \\
{$\left[\mathrm{CaCl}_{2} \cdot 2 \mathrm{H}_{2} \mathrm{O}\right]$} & 0.008 & 1.8 & 1.3 & 7 \\
& 0.03 (standard) & 1.7 & 1.3 & 8 \\
& 0.54 & 1.3 & 2.2 & 10 \\
$\mathrm{Na}^{+}\left[\mathrm{NaCl}^{a}\right.$ & 1.35 & 1.3 & 2.2 & 11 \\
& 0 (no addition) & 2.2 & 1.1 & 8 \\
& 0.008 & 2.2 & 1.1 & 8 \\
& 0.04 (standard) & 2.4 & 1.0 & 8 \\
& 0.39 & 2.0 & 1.2 & 7 \\
\hline
\end{tabular}

$a \quad \mathrm{Na}_{2} \mathrm{MoO}_{4} \cdot 2 \mathrm{H}_{2} \mathrm{O}$ was excluded from medium, and $\left(\mathrm{NH}_{4}\right)_{6} \mathrm{Mo}_{7} \mathrm{O}_{24} \cdot 4 \mathrm{H}_{2} \mathrm{O}$ was added as $\mathrm{MoO}_{4}{ }^{2-}$ source.

Table 3. Effects of major anions.

\begin{tabular}{llccc}
\hline Ion [compound] & \multicolumn{1}{c}{$\begin{array}{c}\text { Ion } \\
\text { concentration } \\
(\mathrm{g} / \mathrm{l})\end{array}$} & $\begin{array}{c}\text { Total cell } \\
\text { number } \\
\left(\times 10^{8} / \mathrm{ml}\right)\end{array}$ & $\begin{array}{c}\text { Lipid content } \\
\left(\mathrm{mg} / 10^{5}\right. \\
\text { cells })\end{array}$ & $\begin{array}{c}\text { Lipid yield } \\
\text { (g of lipid/ } \\
100 \mathrm{~g} \text { of } \\
\text { glucose } \\
\text { consumed) }\end{array}$ \\
\hline $\mathrm{PO}_{4}{ }^{3-}$ & 0 (no addition) & 0.03 & & \\
{$\left[\mathrm{NaH}_{2} \mathrm{PO}_{4} \cdot 2 \mathrm{H}_{2} \mathrm{O}\right]^{a}$} & 0.075 & 1.8 & 1.6 & 11 \\
& 0.75 (standard) & 1.6 & 1.8 & 10 \\
$\mathrm{Cl}^{-}[\mathrm{NaCl}]^{b}$ & 3.75 & 1.7 & 2.1 & 11 \\
& 0 (no addition) & 2.0 & 0.8 & 8 \\
& 0.009 & 2.1 & 1.2 & 10 \\
$\mathrm{SO}_{4}{ }^{2-}\left[\mathrm{Na}_{2} \mathrm{SO}_{4}\right]^{c}$ & 0.09 (standard) & 2.1 & 1.1 & 9 \\
& 0.9 & 2.1 & 1.1 & 9 \\
& 0 (no addition) & 0.03 & & 10 \\
& 0.12 & 1.8 & 1.5 & 9 \\
& 3.56 (standard( & 1.6 & 1.6 & 9 \\
\hline
\end{tabular}

a $\mathrm{KH}_{2} \mathrm{PO}_{4}$ was excluded from medium, and $\mathrm{KCl}$ was added as $\mathrm{K}^{+}$source. $\mathrm{pH}$ of medium was adjusted with $0.2 \mathrm{~N} \mathrm{HCl}$ instead of $0.2 \mathrm{M} \mathrm{H}_{3} \mathrm{PO}_{4}$.

$b \quad \mathrm{CaCl}_{2} \cdot 2 \mathrm{H}_{2} \mathrm{O}, \mathrm{FeCl}_{3} \cdot 6 \mathrm{H}_{2} \mathrm{O}, \mathrm{MnCl}_{2} \cdot 4 \mathrm{H}_{2} \mathrm{O}$, and $\mathrm{CuCl}_{2} \cdot 2 \mathrm{H}_{2} \mathrm{O}$ were excluded from medium. $\mathrm{Fe}_{2}\left(\mathrm{SO}_{4}\right)_{3}, \mathrm{MnSO}_{4}$, and $\mathrm{CuSO}_{4} \cdot 5 \mathrm{H}_{2} \mathrm{O}$ were added as $\mathrm{Fe}^{3+}, \mathrm{Mn}^{2+}$, and $\mathrm{Cu}^{2+}$ sources. The medium did not contain $\mathrm{Ca}^{2+}$ source.

c $\left(\mathrm{NH}_{4}\right)_{2} \mathrm{SO}_{4}, \mathrm{MgSO}_{4} \cdot 7 \mathrm{H}_{2} \mathrm{O}$, and $\mathrm{ZnSO}_{4} \cdot 7 \mathrm{H}_{2} \mathrm{O}$ were excluded from medium. $\mathrm{NH}_{4} \mathrm{Cl}$, $\mathrm{MgCl}_{2} \cdot 6 \mathrm{H}_{2} \mathrm{O}$, and $\mathrm{ZnCl}_{2}$ were added as $\mathrm{NH}_{4}{ }^{+}, \mathrm{Mg}^{2+}$, and $\mathrm{Zn}^{2+}$ sources.

$\mathrm{Mg}^{2+}, \mathrm{PO}_{4}{ }^{3-}$, or $\mathrm{SO}_{4}{ }^{2-}$ (Tables 1 and 3). The total cell number in the no addition of $\mathrm{Zn}^{2+}, \mathrm{Fe}^{3+}$, or $\mathrm{Mn}^{2+}$ was 30-60\% of that in the standard medium (Table 4). Total cell number increased with the increase in $\mathrm{Mn}^{2+}$ concentration (Table 4).

Lower and higher initial $\mathrm{pH}$ values (outside of the range 3.7-4.9), lower and 
Table 4. Effects of minor cations.

\begin{tabular}{llccc}
\hline Ion [compound] & \multicolumn{1}{c}{$\begin{array}{c}\text { Ion } \\
\text { concentration } \\
(\mathrm{mg} / \mathrm{l})\end{array}$} & $\begin{array}{c}\text { Total cell } \\
\text { number } \\
\left(\times 10^{8} / \mathrm{ml}\right)\end{array}$ & $\begin{array}{c}\text { Lipid content } \\
\left(\mathrm{mg} / 10^{8}\right. \\
\text { cells })\end{array}$ & $\begin{array}{c}\text { Lipid yield } \\
\text { (g of lipid/ } \\
\text { 100 g of } \\
\text { glucose } \\
\text { consumed) }\end{array}$ \\
\hline $\mathrm{Zn}^{2+}$ & 0 (no addition) & 0.4 & 4.5 & 15 \\
{$\left[\mathrm{ZnSO}_{4} \cdot 7 \mathrm{H}_{2} \mathrm{O}\right]$} & 0.015 & 0.9 & 3.9 & 14 \\
& 0.075 (standard) & 1.5 & 1.6 & 8 \\
& 1.5 & 1.8 & 1.1 & 6 \\
$\mathrm{Fe}^{3+}\left[\mathrm{FeCl}_{3} \cdot 6 \mathrm{H}_{2} \mathrm{O}\right]$ & 0 (no addition) & 1.8 & 1.1 & 6 \\
& 0.04 & 0.5 & 1.1 & 9 \\
& 0.5 (standard) & 1.6 & 1.6 & 11 \\
& 5.0 & 1.7 & 1.7 & 9 \\
$\mathrm{Mn}^{2+}$ & 50.0 & 1.6 & 1.6 & 9 \\
{$\left[\mathrm{MnCl}_{2} \cdot 4 \mathrm{H}_{2} \mathrm{O}\right]$} & 0 (no addition) & 1.6 & 1.7 & 9 \\
& 0.0022 & 0.9 & 0.7 & 4 \\
& 0.022 (standard) & 1.0 & 1.6 & 7 \\
& 0.22 & 1.5 & 1.7 & 8 \\
$\mathrm{Cu}^{2+}\left[\mathrm{CuCl}_{2} \cdot 2 \mathrm{H}_{2} \mathrm{O}\right]$ & 2.2 & 2.2 & 0.8 & 6 \\
& 0 (no addition) & 2.5 & 0.7 & 6 \\
& 0.0007 & 1.5 & 2.0 & 10 \\
& 0.007 (standard) & 1.6 & 1.9 & 10 \\
& 0.07 & 1.7 & 1.5 & 9 \\
& 0.7 & 1.8 & 1.4 & 8 \\
& 2.0 & 1.3 & 9 \\
\hline
\end{tabular}

Table 5. Effects of minor anions and biotin.

\begin{tabular}{|c|c|c|c|c|}
\hline Ion [compound] & $\begin{array}{c}\text { Ion } \\
\text { concentration } \\
(\mathrm{mg} / \mathrm{l})\end{array}$ & $\begin{array}{c}\text { Total cell } \\
\text { number } \\
\left(\times 10^{8} / \mathrm{ml}\right)\end{array}$ & $\begin{array}{l}\text { Lipid content } \\
\text { (mg/10 } 10^{8} \\
\text { cells })\end{array}$ & $\begin{array}{l}\text { Lipid yield } \\
\text { (g of lipid/ } \\
100 \mathrm{~g} \text { of } \\
\text { glucose } \\
\text { consumed) }\end{array}$ \\
\hline \multirow[t]{5}{*}{$\mathrm{BO}_{3}{ }^{3-}\left[\mathrm{H}_{3} \mathrm{BO}_{3}\right]$} & 0 (no addition) & 1.6 & 1.6 & 8 \\
\hline & 0.004 & 1.6 & 1.4 & 8 \\
\hline & 0.041 (standard) & 1.6 & 1.6 & 9 \\
\hline & 0.41 & 1.6 & 1.5 & 8 \\
\hline & 4.05 & 1.6 & 1.5 & 8 \\
\hline \multirow[t]{5}{*}{$\mathrm{I}^{-}[\mathrm{KI}]$} & 0 (no addition) & 1.8 & 1.2 & 8 \\
\hline & 0.0009 & 1.9 & 1.3 & 8 \\
\hline & 0.009 (standard) & 1.6 & 1.6 & 9 \\
\hline & 0.093 & 1.6 & 1.5 & 8 \\
\hline & 0.93 & 1.6 & 1.5 & 8 \\
\hline $\mathrm{MoO}_{4}{ }^{2-}$ & 0 (no addition) & 1.6 & 1.8 & 9 \\
\hline \multirow[t]{4}{*}[\mathrm{Na}_{2}\mathrm{MoO}_{4}\cdot2\mathrm{H}_{2}\mathrm{O}]{} & 0.00022 & 1.5 & 1.5 & 8 \\
\hline & 0.0022 (standard) & 1.6 & 1.6 & 9 \\
\hline & 0.022 & 1.8 & 1.4 & 8 \\
\hline & 0.22 & 1.8 & 1.4 & 9 \\
\hline \multirow[t]{5}{*}{ D-Biotin } & 0 (no addition) & 1.9 & 1.8 & 11 \\
\hline & 0.00002 & 1.9 & 1.7 & 11 \\
\hline & 0.0002 (standard) & 2.1 & 1.6 & 11 \\
\hline & 0.002 & 2.1 & 1.5 & 11 \\
\hline & 0.02 & 2.1 & 1.4 & 10 \\
\hline
\end{tabular}


Table 6. Effects of cultural conditions.

\begin{tabular}{|c|c|c|c|c|}
\hline Condition & & $\begin{array}{l}\text { Total cell } \\
\text { number } \\
\left(\times 10^{8} / \mathrm{ml}\right)\end{array}$ & $\begin{array}{c}\text { Lipid } \\
\text { content } \\
\text { (mg/10 } \\
\text { cells) }\end{array}$ & $\begin{array}{l}\text { Lipid yield } \\
\text { (g of lipid/ } \\
100 \mathrm{~g} \text { of } \\
\text { glucose } \\
\text { consumed) }\end{array}$ \\
\hline \multirow[t]{5}{*}{ Initial $\mathrm{pH}^{a}$} & 1.8 & 1.1 & 0.9 & 6 \\
\hline & 3.7 & 2.1 & 1.2 & 9 \\
\hline & 4.9 (standard) & 2.2 & 1.6 & 12 \\
\hline & 5.6 & 1.5 & 1.3 & 11 \\
\hline & 6.6 & 0.07 & & \\
\hline \multirow[t]{6}{*}{ Temperature $\left({ }^{\circ} \mathrm{C}\right)$} & 9 & 0.02 & & \\
\hline & 15 & 0.4 & 0.3 & 6 \\
\hline & 19 & 1.1 & 1.2 & 11 \\
\hline & 25.5 & 2.0 & 1.6 & 11 \\
\hline & 29.5 (standard) & 1.7 & 1.8 & 10 \\
\hline & 35 & 0.007 & & \\
\hline \multirow{3}{*}{$\begin{array}{l}\text { Dissolved oxygen } \\
\text { concentration }^{b}\end{array}$} & Low $^{c}$ & 0.8 & 0.5 & 6 \\
\hline & Standard $^{d}$ & 1.5 & 1.9 & 11 \\
\hline & High $^{e}$ & 1.7 & 1.7 & 12 \\
\hline
\end{tabular}

a $\mathrm{pH}$ values were measured after autoclaving.

$b$ Dissolved oxygen concentration in culture medium was shown in Fig. 1.

c Cotton plug on 500-ml shaking flask containing $100 \mathrm{ml}$ of medium was covered with polyethylene-film (thickness $0.06 \mathrm{~mm}$ ).

$d$ One hundred $\mathrm{ml}$ of medium in 500-ml shaking flask.

e Fifty $\mathrm{ml}$ of medium in 500-ml shaking flask.

Table 7. Effects of glucose concentration and carbon sources.

\begin{tabular}{lccccc}
\hline $\begin{array}{c}\text { Carbon } \\
\text { Source }\end{array}$ & $\begin{array}{c}\text { Concen- } \\
\text { tration } \\
(\mathrm{g} / l)\end{array}$ & $\begin{array}{c}\text { Total cell } \\
\text { number } \\
\left(\times 10^{8} / \mathrm{ml}\right)\end{array}$ & $\begin{array}{c}\text { Lipid } \\
\text { content } \\
\left(\mathrm{mg} / 10^{8} \text { cells }\right)\end{array}$ & $\begin{array}{c}\text { Lipid } \\
\text { yield }^{a}\end{array}$ & $\begin{array}{c}\text { Culture } \\
\left.\text { time }^{(h r}\right)^{b}\end{array}$ \\
\hline D-Glucose & 10 & 1.1 & 0.7 & 7 & 53 \\
& 20 & 1.4 & 1.4 & 10 & 78 \\
& 30 (standard) & 1.5 & 2.0 & 10 & 92 \\
& 40 & 1.4 & 2.4 & 8 & 116 \\
Maltose & 50 & 1.4 & 3.0 & 8 & 164 \\
D-Mannose & 30 & 1.3 & 3.8 & 7 & 188 \\
D-Galactose & 30 & 2.0 & 0.6 & 7 & 92 \\
D-Levulose & 30 & 1.4 & 2.3 & 11 & 92 \\
Sucrose & 30 & 1.6 & 1.8 & 11 & 92 \\
Starch & 30 & 1.5 & 2.0 & 10 & 92 \\
Inulin & 30 & 1.4 & 2.3 & 11 & 92 \\
D-Xylose & 30 & 1.9 & 1.2 & 11 & 102 \\
Citrate & 30 & 1.8 & 1.2 & 9 & 102 \\
L-Arabinose & 30 & 1.8 & 2.1 & 13 & 116 \\
Lactose & 30 & 1.1 & 0.8 & 6 & 164 \\
Lactate & 30 & 1.3 & 2.0 & 17 & 188 \\
\hline
\end{tabular}

a Grams of lipid per $100 \mathrm{~g}$ of carbon source consumed.

$b$ The yeast was harvested in this culture time, and the culture time was in stationary phase of growth. 


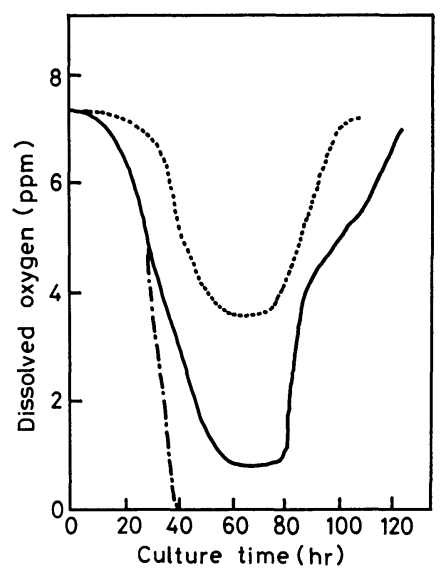

Fig. 1. Variation profiles of dissolved oxygen concentration in culture medium. Dissolved oxygen concentration in medium was monitored continuously with an oxygen-electrode. _ - : standard condition with cotton plug (100 ml of medium in $500-\mathrm{ml}$ shaking flask), - - - . : the cotton plug was covered with polyethylene-film (thickness $0.06 \mathrm{~mm}$ ), ------: culture medium was limited to $50 \mathrm{ml}$ under standard condition.

higher cultural temperatures (outside of the range $25.5-29.5^{\circ} \mathrm{C}$ ), and a low concentration of dissolved oxygen in the medium reduced the total cell number (Table 6 and Fig. 1).

\section{Factors affecting lipid content and lipid yield}

Results of lipid content and lipid yield were obtained only in cases where the growth exceeded $0.1 \times 10^{8}$ cells $/ \mathrm{ml}$. A large amount of lipid was accumulated by decreasing concentration of $\mathrm{NH}_{4}{ }^{+}$or $\mathrm{Zn}^{2+}$ below standard concentration and by increasing $\mathrm{Ca}^{2+}$ concentration beyond standard concentration (Tables 1, 2 and 4). The lipid content decreased with the following conditions: $\mathrm{K}^{+}$deficiency, sufficiency of $\mathrm{Zn}^{2+}$ or $\mathrm{Mn}^{2+}$, no addition of $\mathrm{Fe}^{3+}$ or $\mathrm{Mn}^{2+}$, extraordinarily low initial $\mathrm{pH}$ value (1.8), low cultural temperature $\left(15^{\circ} \mathrm{C}\right.$ and $\left.19^{\circ} \mathrm{C}\right)$, and low concentration of dissolved oxygen in the medium (Tables 1, 4, 6, and Fig. 1). The effect of $\mathrm{Zn}^{2+}$ concentration proved to be the most significant (Table 4).

No addition and deficiency of $\mathrm{Zn}^{2+}$ resulted in a high lipid yield. No addition of $\mathrm{Mn}^{2+}$, an extraordinarily low initial $\mathrm{pH}$ value (1.8), a low cultural temperature $\left(15^{\circ} \mathrm{C}\right)$ and a low concentration of dissolved oxygen decreased the lipid yield (Tables 4, 6 and Fig. 1).

\section{Effects of carbon sources on growth and lipid content}

Table 7 shows effects of glucose concentration and carbon sources on the total cell number, lipid content, and lipid yield. Glucose did not affect the total cell 
number within the tested concentration. The lipid content increased with the increase in glucose concentration from $10 \mathrm{~g} / l$ to $100 \mathrm{~g} / l$.

All carbon sources tested in this work were assimilated by L. starkeyi with the exception of lactose and lactate. The total cell number in many carbon sources was equivalent to that in glucose. The cellular lipid content in maltose starch, inulin, and citrate was lower than that in glucose. Maltose and citrate decreased the lipid yield. L-arabinose provided a higher lipid yield comparison with glucose.

\section{DISCUSSION}

In comparison with the value obtained from the experiment of standard concentration, the effects of the deficiency or the sufficiency of medium component on total cell number, lipid content, and on lipid yield of $L$. starkey $i$ can be classified into four groups (Tables 1-5). Biotin, $\mathrm{MoO}_{4}{ }^{2-}, \mathrm{I}^{-}, \mathrm{BO}_{3}{ }^{3-}, \mathrm{Cu}^{2+}, \mathrm{Cl}^{-}$and $\mathrm{Na}^{+}$ belong to the first group; their concentrations had almost no effect on total cell number, lipid content, and lipid yield. The second group consisted of $\mathrm{NH}_{4}{ }^{+}, \mathrm{K}^{+}$, $\mathrm{Mg}^{2+}, \mathrm{PO}_{4}{ }^{3-}, \mathrm{SO}_{4}{ }^{2-}$, and $\mathrm{Fe}^{3+}$. The no addition and deficiency of these ions increased or decreased total cell number, lipid content, and lipid yield, but the sufficiency of these ions did not increase or decrease them. A sufficient amount of $\mathrm{Ca}^{2+}$ (the third group) increased the lipid content. The no addition, deficiency, and sufficiency of $\mathrm{Zn}^{2+}$ and $\mathrm{Mn}^{2+}$, the members of the fourth group, increased or decreased total cell number, lipid content, and lipid yield. These results also indicate that the second and fourth group ions are essential to the normal growth of L. starkeyi.

Our preliminary study has suggested that the total cell number and the lipid content of $L$. starkeyi were affected by concentrations of $\mathrm{NH}_{4}{ }^{+}, \mathrm{Mn}^{2+}$, and $\mathrm{Zn}^{2+}$ (6). This previous suggestion is confirmed by the present work.

When the cotton plug of the shaking flask was covered with polyethylenefilm, dissolved oxygen in the medium was not detected after $40 \mathrm{hr}$ (Fig. 1). The total cell number under this condition was approximately one half of the standard cultural condition (Table 6). This fact suggests that L. starkeyi was a highly aerobic yeast.

Significance of the ratio of carbon source to the nitrogen source has been presented in studies of the lipid accumulation by microorgansims $(3,4,11,12)$. In this work, we demonstrated that important factors for lipid accumulation of $L$. starkeyi were not only the $\mathrm{C} / \mathrm{N}$ balance but also an adequate concentration of several inorganic ions, especially $\mathrm{Zn}^{2+}$ (Tables 1, 4, and 7). The new finding of $\mathrm{Zn}^{2+}$ effect was achieved by using chemicals and water of the highest purity. These conditions were assumed to be quite difficult to attain in the era of 19401960. 


\section{REFERENCES}

1) J. B. M. Rattray, A. Schibeci and D. K. Kidby, Bacteriol. Rev., 39, 197 (1975).

2) R. L. Starkey, J. Bacteriol., 51, 33 (1946).

3) J. D. Weete, Fungal Lipid Biochemistry, Plenum Press, New York and London (1974), p. 16.

4) M. Woodbine, Prog. Ind. Microbiol., 1, 181 (1959).

5) T. Naganuma, Y. Uzuka, K. Tanaka and T. Koga, Nippon Nogeikagaku Kaishi, 49, 335 (1975).

6) H. Korenaga, T. Naganuma, Y. Uzuka and K. Tanaka, Nippon Nogeikagaku Kaishi, 51, 449 (1977).

7) Y. Uzuka, T. Naganuma, K. Tanaka and Y. Odagiri, J. Gen. Appl. Microbiol., 20, 197 (1974).

8) C. O. Gill, M. J. Hall and C. Ratledge, Appl. Environ. Microbiol., 33, 231 (1977).

9) J. E. Hodge and B. T. Hofreiter, In Methods in Carbohydrate Chemistry I, ed. by R. L. Whistler and M. L. Wolfrom, Academic Press, New York and London (1962), p. 388.

10) T. Nomura, Y. Hashimoto, K. Shiga and K. Tanaka, J. Inst. Enol. Vitic. Yamanashi Univ., 15, 23 (1980).

11) C. Ratledge, In Food from Waste, ed. by G. G. Birch, K. J. Parker and J. T. Worgan, Applied Science Publishers Ltd., London (1976), p. 98.

12) D. A. Whitworth and C. Ratledge, Process Biochem., 9, 14 (1974). 